\title{
Transitional justice, transformative justice, democracy and development
}

This chapter explores the relationships between transitional justice, transformative justice, democracy and development. Concentrating on the ways in which these concepts and their practice both overlap and diverge, the chapter considers the extent to which transitional justice and development could become mutually constitutive as well as challenges to this. The chapter argues that established, narrow approaches to transitional justice are less likely to contribute towards development than broader transformative justice approaches. Moreover, it is argued that narrow approaches to development can work against - or at least fail to contribute towards - some of the (supposed) ends of transitional justice. The chapter argues that transformative justice and broader understandings of development are more synergistic. However, it is nevertheless the case that transitional (and transformative) justice cannot fully absorb or be absorbed into development. Different (though not outright contradictory) foci ought to be maintained. The chapter concludes by positing that it is necessary for advocates of transitional justice and development (and transformative justice) to maintain a concern for democracy (what it is, in which processes it might be implemented and how it might be promoted) in order to realise the potential, and avoid the pitfalls, of considering transitional justice and development together.

Keywords:

Transitional justice; transformative justice; democracy; development; human rights; participation Biography:

Matthew Evans is a Lecturer in Law, Politics and Sociology at the University of Sussex, Brighton, UK and Visiting Researcher in Political Studies at the University of the Witwatersrand, Johannesburg, South Africa. His research focuses upon human rights, especially socioeconomic rights, transformative justice, and the relationships between social movements, nongovernmental organisations and trade unions. Recent publications include Transformative Justice: Remedying Human Rights Violations Beyond Transition (Routledge, 2018) and (as editor) Transitional and Transformative Justice: Critical and International Perspectives (Routledge, 2019). 


\section{Transitional justice, transformative justice, democracy and development}

This chapter explores the relationships between transitional justice, transformative justice, democracy and development. Concentrating on the ways in which these concepts and their practice both overlap and diverge, the chapter considers the extent to which transitional justice and development could become mutually constitutive as well as challenges to this. The chapter argues that established, narrow approaches to transitional justice are less likely to contribute towards development than broader transformative justice approaches. Moreover, it is argued that narrow approaches to development can work against - or at least fail to contribute towards - some of the (supposed) ends of transitional justice. The chapter argues that transformative justice and broader understandings of development are more synergistic. However, it is nevertheless the case that transitional (and transformative) justice cannot fully absorb or be absorbed into development. Different (though not outright contradictory) foci ought to be maintained. The chapter concludes by positing that it is necessary for advocates of transitional justice and development (and transformative justice) to maintain a concern for democracy (what it is, in which processes it might be implemented and how it might be promoted) in order to realise the potential, and avoid the pitfalls, of considering transitional justice and development together. 


\section{Introduction}

In recent years scholarship considering the relationship between transitional justice and development has emerged (see, for example, de Greiff and Duthie 2009; Mani 2008; Selim and Murithi 2011). At the same time, critical literatures within both areas of study have come to prominence. In addition to questioning the orthodoxies and mainstream assumptions of these fields, more and more critical literature on transitional justice and development consciously pivots towards interdisciplinarity and the breaking down of boundaries between these (and other) areas of scholarship and practice (see, for example, Bell 2009; Huggins 2009; Evans 2018a; Evans 2019). It is in this context that scholarly attention in some quarters has turned to the development, promotion and application of the concept of transformative justice (see, for example, Gready and Robins 2014; Evans 2018a). Conceived as building upon and providing an alternative to transitional justice, transformative justice seeks to address some of the shortcomings of transitional justice identified in the critical literature (see, for example, Daly 2002; Andrieu 2010; Gready and Robins 2014; McAuliffe 2017; Lambourne 2014; Evans 2018a). In so doing, transformative justice overlaps with the concerns (and tools) of both transitional justice and development.

This chapter first sets out the conceptual and practical overlaps between the concepts of transitional justice, transformative justice and development. Following this, divergences are then explored. It is argued that established, narrow approaches to transitional justice are less likely to contribute towards development than broader transformative justice approaches. Moreover, it is argued that narrow approaches to development can work against - or at least fail to contribute towards - some of the (supposed) ends of transitional justice. These sections are subsequently built upon as the chapter addresses the question of whether transitional justice and development can become mutually constitutive. Here it is argued that transformative justice and broader understandings of development are more synergistic than narrow conceptions but that transitional (and transformative) justice cannot fully absorb or be absorbed into development. Finally, the 
chapter concludes that it is necessary for advocates of transitional justice and development (and transformative justice) to maintain a concern for democracy in order to realise the potential, and avoid the pitfalls, of considering transitional justice and development together.

\section{Conceptual and practical overlaps}

Transitional justice and development overlap in a number of ways. This is especially the case with regard to broad, heterodox and critical approaches to both concepts. Transitional justice tends to be defined with regard to states' (especially) and non-state actors' attempts to facilitate a society's recovery from conflict and authoritarianism and promote particular notions such as reconciliation, peace and justice (see, for example, de Greiff 2010, p. 2; International Center for Transitional Justice n.d.; Annan 2004). ${ }^{1}$ Whilst definitions do not necessarily list particular mechanisms or means of pursuing these goals, a particular toolkit of mainstream transitional justice has become established, focusing especially on criminal trials and amnesties, truth commissions, reparations programmes and institutional reforms such as vetting of government employees (see, for example, Annan 2004; International Center for Transitional Justice n.d.; Andrieu 2010; Sandoval Villalba 2011; Gready and Robins 2014). Narrow, longer-established approaches to transitional justice have tended to focus on the application of these mechanisms to addressing gross violations of civil and political rights, especially those related to direct interpersonal violence and bodily integrity (see, for example, Gready and Robins 2014; Waldorf 2012).

Development, on the other hand, has been defined largely in regard to measures of poverty reduction, and (in narrow but longer-established conceptions) especially in relation to economic growth as a proxy for this (see, for example, Barder 2012). In relatively recent years increased attention has been paid to approaching development from perspectives which take account of, or overlap with, human rights (see, for example, Sen 1999; Marks 2003; Uvin 2004; Alston 2005; Alston 
and Robinson 2005). The emergence of concepts such as human development as well as various conceptions of human rights-based approaches to development focus attention away from a narrow concern with economic development, especially understood as growth (see, for example, Sen 1999).

Stephen Marks (2003), for instance, considers seven approaches to linking human rights and development. These are 'the holistic approach, the rights (or human rights) based approach, the social justice approach, the capabilities approach, the right to development approach, the responsibilities approach, and the human rights education approach' (Marks, 2003 p. 2; emphasis removed).

The holistic approach 'connects all human rights, dispensing with many of the traditional distinctions between categories of rights' (i.e. between civil and political rights and socioeconomic rights, or between negative freedoms and positive freedoms) and 'recognizes that both categories require resources, both can involve violations, both require adaptation and often transformation of institutions and practices, and both are essential for human dignity' (Marks 2003, pp. 3-4). According to Marks, '[i]n the context of development, the holistic approach means that all human rights, not just the right that appears most relevant to the task at hand, must be considered' (Marks 2003, p. 5).

The rights based approach 'affirm[s] that development should be pursued in a "human rights way"' (Marks 2003, p. 5). For development, this means 'integrat[ing] concepts that already had currency in development theory-such as accountability and transparence [sic] in the context of good governance-and add[ing] ... explicit reference to government obligations deriving from international human rights law and procedures' (Marks 2003, p. 6).

The social justice approach 'captures an important feature of the human rights framework for development, namely the emphasis on the moral imperative of eliminating glaring social inequality within societies and structurally-imbedded patterns of international support for those inequalities' (Marks 2003, p. 8). It emerges in the context of '[h]uman rights frequently becom[ing] a 
surrogate for social justice, the assumption being that what contributes to social justice in the context of development is also a contribution to human rights' (Marks 2003, p. 7). Using Oxfam International's approach as an example, Marks argues that the social justice approach does not apply 'human rights in the terminology used in the international human rights texts', instead it makes use of 'interpretations of social justice that can be justified using those texts' (Marks 2003, p. 8).

The capabilities approach is based largely upon Amartya Sen's work (see, for example, Sen, 1999), as well as that of Martha Nussbaum, arguing that 'development is not the acquisition of more goods and services but the enhanced freedom to choose, to lead the kind of life one values' and that '[t]hese enhanced choices are called capabilities' (Marks 2003, p. 9). Moreover, as this approach 'links development concerns to freedom' and 'freedom implies the widening of choices in the civil, political, social, economic, and cultural spheres, each of the capabilities ... may be contemplated as a starting point for a human rights understanding of the development process' (Marks 2003, p. 12).

The right to development approach is 'to consider development itself as a human right' (Marks 2003, p. 12). It is distinguishable from the rights based approach because 'the right to development is broader that the human rights-based approach, encompassing a critical examination of the overall development process, including planning, participation, allocation of resources, and priorities in international development cooperation' (Marks 2003, p. 16). Despite what Marks calls the 'compromised language' of the United Nations' Declaration on the Right to Development being 'far removed from mandating an altered international division of labor or terms of trade or aid', the right to development 'is used rhetorically to amplify Third World demands on the industrialized world for a transfer of resources, in the form of foreign aid or debt forgiveness' (Marks 2003, p. 14). Marks argues that in this approach, the 'challenge from the beginning has been to translate the hopeful but ambiguous language of the Declaration into concepts that are meaningful to economists and useful to the rethinking of the development process' (Marks 2003, p. 14). He argues, further, 
that attempts at this have been made and notes 'the effort to move from political rhetoric to development practice is one of the most welcome trends since the Declaration was adopted in 1986' (Marks 2003, p. 15).

The responsibilities approach is focused upon 'obligations in the human rights field' (such as to respect, protect and fulfil human rights) (Marks 2003, p. 22). These obligations 'are primarily those of governments. However, individuals and non-state entities have obligations as well, and governments have a duty to ensure that these non-state actors do not violate human rights in their relations with others' (Marks 2003, p. 22). Furthermore, a responsibilities approach takes account of the 'legitimate limitations [which] may be placed on rights so that they may be exercised responsibly', whilst noting 'these limitations are not a license to governments to evade their duties' (Marks 2003, pp. 22-3).

The human rights education approach is 'close to the concept of community-based development work or participatory action research' (Marks 2003, p. 23). It is based on the idea that 'the most effective means of enhancing people's capabilities is to facilitate their own social transformation through participation in the decisions that affect development' (Marks 2003, p. 23) and contributes to development through 'helping monitor development activities', 'mobilizing support for victims' struggles for rehabilitation, redress, and justice', 'promoting understanding of the rationale for development', 'securing more effective participation in the development process' and 'securing accountability for those responsible for misuse of public resources' (Marks 2003, p. 24).

Furthermore, recent scholarship has emphasised the ways in which development especially understood broadly, as in human development - affects and is affected by transitional justice (see, for example, Mani 2008; de Greiff and Duthie 2009). Calls have been made for the expansion of the focus of mainstream transitional justice tools and processes such as truth commissions and reparations programmes to take account of socioeconomic conditions rather than 
focusing only - or predominantly - on addressing instances of direct interpersonal violence and violations of a narrow range of civil and political rights (see, for example, Selim and Murithi 2011; Skaar 2011; Schmid and Nolan 2014). It has for instance, been argued that 'transitional justice should include aspects of development (by incorporating distributive justice measures) to strengthen its contributions to peacebuilding' (Selim and Murithi 2011, p. 59). Likewise, the idea that socioeconomic aspects of development ought to be considered in the design and implementation of transitional justice programmes has been put forward as necessary in order to address root causes of conflict and to prevent a return to violence in post-transitional societies (see, for example, Muvingi 2009; Mani 2008; Laplante 2008).

Rama Mani, however, argues that (whilst necessary) expanding the focus of transitional justice to take account of social injustice and development-related concerns presents a number of dilemmas (Mani 2008, p. 254). The first dilemma concerns the difficulty inherent in applying the targeted measures associated with transitional justice (truth commissions, trials and institutional reform) to the wide-reaching effects of social injustice. The lack of clearly identifiable individuals as victims and perpetrators does not map easily on to existing models of transitional justice mechanisms (Mani 2008, p. 255; see also Mamdani 1996). The second dilemma concerns the fact that transitional justice is expensive to implement and, in the absence of addressing social injustice and structural violence, may not be viewed as a priority for resource distribution (Mani 2008, pp. 256-7). Relatedly, Mani's third dilemma surrounds the question of how transitional justice processes can address corrupt and exploitative economic conditions during conflicts which, as a result, impact upon the capacity for facilitating development post-conflict (Mani 2008, pp. 257-9). Mani's final dilemma is concerned with the failure of both transitional justice and development theory and practice to address post-conflict criminal and societal violence - as opposed to 'political' violence despite the link between what is viewed as criminal violence and social injustice or structural violence (Mani 2008, pp. 259-61; see also, for example, Gready 2011; von Holdt 2013). 
Recent moves towards transitional justice being used to address socioeconomic inequalities, and the consequent production of dilemmas such as those raised above (see Mani 2008), have engendered a range of responses. These include allowing further space for the airing of socioeconomic grievances in truth commissions and specifically addressing development-related issues (for instance, societal injustices such as land inequalities) through reparations (Pasipanodya 2008, pp. 392-5; see also, Firchow 2013; Bergsmo et al. 2010). Related to this scholarship has been the emergence of literature seeking to define and promote transformative justice either as an approach within or alternative to transitional justice, taking greater account of socioeconomic rights, structural violence, long term societal change and participation of affected communities (Daly 2002; Gready and Robins 2014; Lambourne 2014; Evans 2016; see also Sandoval 2017). The conceptual and practical overlap with development is especially clear with regard to calls for transformative justice to be pursued using a different toolkit to that typically applied in transitional justice. In this sense it is possible - perhaps even likely - that the same policies and practices which promote development also promote transformative justice (see, for example, Huggins 2009). As has been argued elsewhere, " $[\mathrm{w}]$ ith regard to the mechanisms that might be employed in order to promote transformative justice, there is a case to be made that existing tools designed for combating poverty, inequality, or corruption, for instance, are appropriate' (Evans 2016, p. 9). However, such tools would only contribute to transformative justice, as opposed to broader notions of social justice, if they addressed present-day poverty rooted in injustice caused by a past period of conflict or authoritarianism (Evans 2016, p. 9). Likewise, Clara Sandoval argues that ' $[\mathrm{t}]$ ransitional justice mechanisms have not been designed to achieve social justice, development, democracy, rule of law, or peace in themselves, but they can contribute toward the realization of some of these goals' (Sandoval 2017, p. 185). This points to both the potential overlaps between and the necessary divergence of transitional (and transformative) justice and development. These divergences are explored next. 


\section{Divergence}

Despite the abovementioned overlaps between the concepts and practice of development and transitional justice (and transformative justice), there are nevertheless a number of divergences that must be recognised. Perhaps most obviously, in their more narrowly defined forms transitional justice and development may have little in common in terms of aims. Given their divergent aims, transitional justice and development might, under some circumstances, work against each other in practice.

If development is narrowly defined as the pursuit of economic growth, for instance, this is unlikely to contribute towards, and might undermine, the pursuit of transitional justice focussed upon trials, truth commissions and reparations programmes. Indeed, with regard to reparations programmes, one frequently cited reason for these not being pursued (or not to the extent recommended) is the economic cost to the state (see, for example, Waldorf 2012, pp. 177-9; Mani 2008, pp. 256-7). Similarly, where criminal prosecutions are likely to be costly and time-consuming, the pursuit of economic development (at least in terms of growth) might imply a need to deprioritize pursuing trials (see, for example, Mani 2008, pp. 256-257). Economic growth and political stability are also often presented as justifications for pursuing wide-reaching amnesty programmes, which transitional justice advocates may consider as entrenching impunity, rather than more accountabilityfocused transitional justice mechanisms (see, for example, de Greiff 2010, p. 22; Collins 2010; see also Sandoval Villalba 2011, pp. 3-4). Pablo de Greiff notes that, in thinking on development in transitional justice contexts, there is at times a tendency of falling into the trap of accepting the narrative of a dichotomy 'between security and development on the one hand and justice on the other' (de Greiff 2010, p. 22). If this (false) dichotomy is accepted, and narrowly-defined development is prioritized, then the goals of transitional justice are undermined. Likewise, arguing against narrow, technocratic notions of transitional justice, Lundy and McGovern (2008, p. 276) note that 'wider geo-political and 
economic interests too often shape what tend to be represented as politically and economically neutral post-conflict and transitional justice initiatives' (see also Andrieu 2010).

Furthermore, despite the rise to prominence of various kinds of human rights-based approaches to development and indicators such as the Human Development Index (HDI), narrower conceptions of development continue to hold sway (see, for example, Easterly 2006). For example, the conception of development promoted by some influential figures such as William Easterly is a narrow one. Easterly's approach is very much focused on economic growth. In his book The White Man's Burden there is no mention of the HDI at any point (Easterly 2006). Easterly does demonstrate that despite increasing rhetorical commitment to ensuring participation, big aid agencies continue to fail to ensure genuine local ownership of and participation in development projects (Easterly 2006). However, his own proposed model of development does not necessarily resolve these issues, and would not be consistent with the aims of transformative justice or broadly conceived 'developmentsensitive' transitional justice (see, for example, Duthie 2008; Evans 2018a).

Easterly's approach appears to be more concerned with ensuring market principles are incorporated into development projects rather than human rights principles. Though he claims that accountability and participation are better realised through the allegedly creative, bottom-up market approach of 'Searchers' than the top-down bureaucratic approach of 'Planners' (Easterly 2006), this is not necessarily the case. Easterly's focus on economic growth and markets obscures improvements in human development achieved through non-market driven processes as well as the possibility that market-based approaches may undermine human development and/or human rights (see, for example, Griffiths 2003, pp. 167-77; Aberese Ako, Anyidoho and Crawford 2013; Sen 1999). There is also no guarantee that Easterly's favoured market-oriented approaches would in fact be characterised by bottom-up mobilization. Nigel Gibson, for example, argues against the kinds of processes Easterly favours, positing that market-oriented 'boot-strap' programmes such as micro-credit and poor people's savings schemes (which are often favoured by international financial institutions such as the 
World Bank and philanthrocapitalist donor organisations like the Bill and Melinda Gates Foundation) 'often pathologise the poor' (Gibson 2011, p. 272). Moreover, despite the bottom-up rhetoric of advocates such as Easterly, there is every chance these programmes are imposed from above (see, for example, Podlashuc 2011).

The kinds of criteria used to measure human development - indices of child mortality, adult life expectancy and literacy for example - are clearly in line with a number of recognised and legally enshrined human rights such as the right to health and right to education (see, for example, United Nations, 1966; see also Marks 2003). The same cannot so easily be said for economic growth. From a human rights perspective, human development is much more important than economic growth or the opening up of markets. There is no right to markets. There is a right to health. Where economic growth is put forward as the overriding priority of development, this diverges from the (stated) aims of transitional justice, and diverges especially from transformative justice (see, for example, Andrieu 2010; McAuliffe 2017; Evans 2018a). Indeed, development thinkers concerned primarily with growth have at times praised deeply authoritarian and human rights abusing states (see, for example, Easterly 2006). Here, the aims of one conception of development diverge significantly, even with a fairly narrow conception of transitional justice.

\section{Can transitional justice and development become mutually constitutive?}

Transitional justice and development are potentially synergistic when they are conceived and applied in compatible terms. This is more likely to occur on the one hand, when both development and transitional justice are conceived narrowly and, on the other, when both development and transitional justice are conceived more expansively. In the event that development policies and processes are put forward with a different conception and mandate to transitional justice processes then disconnection and contradiction is more likely to manifest. Figure 1, below, indicates the 
relationships between approaches to development and transitional justice. Narrow conceptions of transitional justice overlap with narrow conceptions of development and, to some extent, with expansive conceptions of transitional justice and transformative justice. Broad conceptions of development and human rights-oriented development overlap more with the concerns of expansive transitional and transformative justice, and to some degree with narrower conceptions of development. Narrow conceptions of development and expansive notions of transitional justice do not, however, overlap. ${ }^{2}$

$<$ Figure 1 here $>$

Figure 1: Relationships between approaches to development and transitional justice

Where development and transitional justice are conceived narrowly, they might be mutually constitutive if their aims are focused especially on promoting stability. Cessation of armed conflict and the functioning of liberal markets may in this conception be the mutual aims of transitional justice and development. However, there are good reasons for thinking that such conceptions are problematic (see, for example, Gready and Robins 2014; Lai 2016; Gready 2011, pp. 212-13). From a human rights point of view, other goals ought to be emphasised. Broader goals of transitional (or transformative) justice and the goals of human rights-based approaches to development are likely to be in some ways synergistic, whilst also being (at least potentially) progressive. If, however, there is a disconnect between the broader human rights-based goals of the approach pursued to either development or transitional justice, and a narrow stability-oriented mandate of the other area of intervention then contradictions are more likely.

A key area where there is the potential for a progressive overlap between transitional (and, especially, transformative) justice and development is in the area of democracy and participation (see, for example, Andrieu 2010; Evans 2018a). Taking an approach to development which draws on the increasingly mainstream notions of human rights-based approaches, and development as freedom, it is clear that the opportunities for individuals and communities who are affected by 
development interventions to shape, influence and contest the priorities and forms of these is a good thing. In the sense of maximising freedom and reducing unfreedom, this contributes to development in itself (see, for example, Sen 1999; Marks 2003; Gaventa and Barrett 2010). Likewise, more expansive accounts of transitional justice and, especially, conceptions of transformative justice in post-conflict and post-authoritarian contexts require the participation of affected communities in setting out their own needs and priorities, influencing and contesting elite bargains and institutions (see, for example, Robins and Kumar Bhandari 2012; Gready and Robins 2014; Evans 2016; Evans 2018a). Fundamentally, this is a form of democracy which goes beyond procedural notions of formal democratic processes such as representative elections. This kind of democratic participation is a goal of both transformative justice and human rights-oriented approaches to development. Moreover, this kind of democracy is likely to be crucial in the success or failure of development and transitional (or transformative) justice processes (see, for example, Uvin 2004, p. 138; Gaventa and Barrett 2010; Robins 2013; Evans 2016). Without democracy the other wider goals of human development and transformative justice are less likely to occur. It is important to consider the ways in which this kind of democratic participation can be manifested in the context of development and transitional (or transformative) justice (see, for example, Evans 2018a; Gready and Robins 2017). There is an important role for civil society in producing this kind of democratic process, including with regard to the mobilization of social movements, as well as the participation of affected communities in groups and organisations such as trade unions and nongovernmental organisations (NGOs) (see, for example, Evans 2018a; Gready and Robins 2017; Lai 2016; Ottendörfer et al. 2017).

Nevertheless, there are necessarily differences between the aims and foci of transitional justice (and transformative justice) and development, even when they are conceived and applied in their most mutually constitutive forms. Transitional justice and development cannot and should not be fully absorbed into each other. This is for a number of reasons. First, and perhaps most obviously, transitional justice has a particular concern with transitions from conflict or authoritarianism to peace and democracy. Development does not have such a focus and nor should it. To apply 
development interventions only in situations where societies are attempting to recover from a recent period of conflict or authoritarian rule would arbitrarily exclude large populations from the benefits of development. Indeed, this issue has been raised by scholars critical of the potential for reparations programmes to be selectively applied by states to particular victim communities instead of providing more inclusive development programmes (potentially in addition to reparations for those specifically victimized) (see, for example, Firchow 2013; see also Evans and Wilkins 2017).

Likewise, transitional justice is not only applied in contexts which might be defined as developing countries, or in the global South. On the one hand, a major criticism of some approaches to transitional justice has been its tendency to reproduce an arguably colonial relationship between international (disproportionately Western) actors delivering 'justice' to disempowered recipients in Africa, Asia and Latin America (see, for example, Madlingozi 2010; Lundy and McGovern 2008; Matsunaga 2016). On the other hand, there are good reasons for thinking that transitional justice could be applicable to Western countries and the global North - and in some cases transitional justice processes have taken place, perhaps most notably in Northern Ireland, but also in other contexts such as Canada and Spain (see, for example, Hamber and Kelly 2016; Lundy and McGovern 2008; Encarnación 2008; Davis 2005; Jung 2009; Matsunaga 2016). ${ }^{3}$ In these cases, the link to development as it is usually conceived is less obvious. Moreover, critical approaches to transitional justice, and transformative justice, overtly seek to avoid these problematic dynamics and the imposition of narrowly conceived one-size-fits-all approaches to justice in the wake of conflict and authoritarianism (see, for example, Lundy and McGovern 2008; Robins 2013; Evans 2018a). ${ }^{4}$

Transitional justice and development cannot be fully absorbed into each other. It is possible, however, for both processes to be synergistic. For this to be progressive, it is necessary for conceptions of and approaches to both transitional justice and development to be open to participation and contestation by affected communities and for the realisation of the full range of human rights to be of central concern (see, for example, Evans 2018a; Gready and Robins 2017). 
Elsewhere it has been argued that transformative justice necessitates paying attention to the ways in which members of communities affected by the legacies of conflict, authoritarianism and injustice - including with regard to socioeconomic inequalities and structural violence - mobilize, articulate their concerns and take collective action (see, for example, Evans 2016). As mentioned above, this means taking account of the actions of, and relationships between, organisations and groups such as NGOs, social movements and trade unions (see Evans 2016; Evans 2018a). Mobilization by, and affected community members' participation in, these kinds of groups and organisations is a key way by which the democratic participation deemed necessary above might be achieved (and in a potentially - progressive manner) (see, for example, Evans 2018a; Gready and Robins 2017; see also Evans 2015). ${ }^{5}$

\section{Conclusion}

In order to establish the extent to which development and transitional justice are mutually constitutive it is necessary to consider what the purposes of development and transitional justice are. This chapter argues that wide reaching transformative justice ought to be pursued as part of, or alongside, transitional justice and that notions of development which prioritize human rights are superior to those which focus upon narrower, primarily economic growth-oriented goals. Whilst narrow conceptions of development and transitional justice can indeed be synergistic, these conceptions and applications are potentially problematic and regressive. It is not simply an automatically good thing for development and transitional justice to reinforce one another - this is only desirable in the event that the situation promoted by development and transitional justice is a desirable one.

It is also the case that development and transitional justice (and, indeed, transformative justice) do not and cannot have wholly identical purposes. Even as it is possible that they become mutually constitutive it is not the case that development and transitional justice are or should 
become synonymous. There are distinct areas of focus and priority which it is right that transitional justice and development interventions address distinctly from one another.

By way of conclusion, the following is worth emphasising. First, transitional justice and development do not necessarily overlap to a large degree. Second, an overlap between the concerns and practices of transitional justice and development is possible and, indeed, likely if transitional justice and development interventions are conceived either with regard to narrow goals (such as stability and functioning liberal markets) or with regard to more expansive, broad goals (such as the realisation of socioeconomic rights and maximization of freedom - also broadly conceived). Third, in order for mutual reinforcement of transitional justice and development to be progressive, expansive, broad understandings of both concepts and their application in practice is desirable. In order for this to be realised, a central concern of both transitional justice (and transformative justice) and development must be democracy. For freedom to be maximized as a form of development, and for transformative change to occur in post-conflict or post-authoritarian contexts, the participation of affected communities is necessary. Whilst transitional justice and development can overlap in their more narrowly conceived forms, it is these forms which are most vulnerable to criticism in relation to the deprioritization of local or grassroots actors and their concerns as opposed to elite actors and outside priorities.

It may be concluded, then, that more expansive notions of both development and transitional justice ought to be promoted, maintaining a key focus on facilitating democratic participation. As such, transformative justice is more desirable and more consistent with human rights inclusive forms of development than established, narrow conceptions of transitional justice. Going forward, the task for scholars and practitioners concerned with the intersection of transitional justice and development is to build upon these insights, and those of the emerging literature, especially with regard to implementation in practice. 
1. These aims do not, however, exist in a political vacuum and are not uncontested. See, for example, Madlingozi, 2010; Mamdani 1996; see also Lai 2016; Evans 2018b.

2. See Evans (2016) for further elaboration on the overlaps and differences between transitional justice and transformative justice.

3. The debatable position of the former Yugoslavia, and of Central and Eastern European countries such as Poland, in relation to binaries such as Western/non-Western and global North/global South brings a simple notion of transitional justice as something done by the West to the rest further into question. The question of the purposes of transitional justice (such as promoting stability and markets or promoting societal transformation and human development) nevertheless remain. On post-transitional dynamics in the former Yugoslavia, see, for example, Lai 2016; Lai and Bonora 2019. On Poland, and Central and Eastern Europe more broadly, see, for example, Kochanowicz 2001; Szczerbiak 2017; Stan 2009.

4. Kora Andrieu, for instance, notes that local initiatives 'may promote participation and a sense of ownership over transitional justice and the peacebuilding process, but they may lose much of their value when encouraged and programmed by the state or by international institutions, as is most often the case' (Andrieu 2010, p. 546).

5. It is, however, important to emphasise that this progressive potential is not certain to be realised. As Andrieu notes, 'we tend to assume, wrongly, that the community is necessarily the repository of solidarity and democratic values', whereas, at times, community mobilizations 'can also be patriarchal and oppressive for individuals, particularly women and minorities' (Andrieu 2010, p. 546).

\section{References}


Aberese Ako, Matilda, Nana Akua Anyidoho and Gordon Crawford (2013), ‘NGOs, Rights-Based Approaches and the Potential for Progressive Development in Local Contexts: Constraints and Challenges in Northern Ghana', Journal of Human Rights Practice, 5(1), 46-74.

Alston, Philip (2005), 'Ships Passing in the Night: The Current State of the Human Rights and Development Debate Seen through the Lens of the Millennium Development Goals', Human Rights Quarterly, 27(3), 755-829.

Alston, Philip and Mary Robinson (eds) (2005), Human Rights and Development: Towards Mutual Reinforcement, Oxford: Oxford University Press.

Andrieu, Kora (2010), 'Civilizing Peacebuilding: Transitional Justice, Civil Society and the Liberal Paradigm', Security Dialogue, 41(5), 537-58.

Annan, Kofi (2004), The Rule of Law and Transitional Justice in Conflict and Post-Conflict Societies, Report of the Secretary-General, United Nations Security Council, 23 August, UN Doc S/2004/616. Barder, Owen (2012), 'What Is Development?', Center for Global Development, 16 August, accessed 18 July 2018 at https://www.cgdev.org/blog/what-development.

Bell, Christine (2009), 'Transitional Justice, Interdisciplinarity and the State of the "Field" or "NonField"', International Journal of Transitional Justice, 3(1), 5-27.

Bergsmo, Morten, César Rodríguez-Garavito, Pablo Kalmanovitz and Maria Paula Saffon (eds) (2010) Distributive Justice in Transition, Oslo: Torkel Opsahl Academic EPublisher.

Collins, Cath (2010), Post-Transitional Justice: Human Rights Trials in Chile and El Salvador, University Park: Pennsylvania State University Press.

Daly, Erin (2002), 'Transformative Justice: Charting a Path to Reconciliation', International Legal Perspectives, 12(1/2), 73-183. 
Davis, Madeleine (2005), 'Is Spain Recovering its Memory? Breaking the Pacto del Olvido', Human Rights Quarterly, 27(3), 858-80.

de Greiff, Pablo (2010), Transitional Justice, Security, and Development: Security and Justice Thematic Paper, World Development Report 2011 Background Paper, 29 October, New York: International Center for Transitional Justice.

de Greiff, Pablo and Roger Duthie (eds) (2009), Transitional Justice and Development: Making Connections, New York: Social Science Research Council.

Duthie, Roger (2008), 'Toward a Development-Sensitive Approach to Transitional Justice', International Journal of Transitional Justice, 2(3), 292-309.

Easterly, William (2006), The White Man's Burden: Why the West's Efforts to Aid the Rest Have Done So Much III and So Little Good, Oxford: Oxford University Press.

Encarnación, Omar G. (2008), 'Reconciliation after Democratization: Coping with the Past in Spain', Political Science Quarterly, 123(3), 435-59.

Evans, Matthew (2015), 'Trade unions as human rights organizations', Journal of Human Rights Practice, 7(3): 466-83.

Evans, Matthew (2016), 'Structural violence, socioeconomic rights and transformative justice', Journal of Human Rights, 15(1), 1-20.

Evans, Matthew (2018a), Transformative Justice: Remedying Human Rights Violations Beyond Transition, Abingdon: Routledge.

Evans, Matthew (2018b), 'A future without forgiveness: Beyond reconciliation in transitional justice', International Politics, 55(5), 678-92. 
Evans, Matthew (ed.) (2019), Transitional and Transformative Justice: Critical and International Perspectives, Abingdon: Routledge.

Evans, Matthew and David Wilkins (2017), 'Transformative Justice, Reparations and Transatlantic Slavery', Social and Legal Studies, DOI: 10.1177/0964663917746490.

Firchow, Pamina (2013), 'Must Our Communities Bleed to Receive Social Services? Development Projects and Collective Reparations Schemes in Colombia', Journal of Peacebuilding and Development, 8(3), 50-63.

Gaventa, John and Gregory Barrett (2010), So What Difference Does it Make? Mapping the Outcomes of Citizen Engagement, IDS Working Paper 347, Institute of Development Studies, University of Sussex, Brighton: Institute of Development Studies.

Gibson, Nigel C. (2011), Fanonian Practices in South Africa: From Steve Biko to Abahlali baseMjondolo, New York: Palgrave Macmillan.

Gready, Paul (2011), The Era of Transitional Justice: The Aftermath of the Truth and Reconciliation Commission in South Africa and Beyond, Abingdon: Routledge.

Gready, Paul and Simon Robins (2014), 'From Transitional to Transformative Justice: A New Agenda for Practice', International Journal of Transitional Justice, 8(3), 339-61.

Gready, Paul and Simon Robins (2017), 'Rethinking civil society and transitional justice: lessons from social movements and "new" civil society', International Journal of Human Rights, 21(7), 956-97.

Griffiths, Peter (2003), The Economist's Tale: A Consultant Encounters Hunger and the World Bank, London: Zed Books.

Hamber, Brandon and Grainne Kelly (2016), 'Practice, Power and Inertia: Personal Narrative, Archives and Dealing with the Past in Northern Ireland', Journal of Human Rights Practice, 8(1), 2544. 
Huggins, Chris (2009), 'Linking Broad Constellations of Ideas: Transitional Justice, Land Tenure Reform, and Development', in Pablo de Greiff and Roger Duthie (eds), Transitional Justice and Development: Making Connections, New York: Social Science Research Council, pp. 332-74.

International Center for Transitional Justice (n.d.), 'What Is Transitional Justice?' accessed 15 September 2014 at http://ictj.org/about/transitional-justice.

Jung, Courtney (2009), Canada and the Legacy of the Indian Residential Schools: transitional justice for indigenous people in a non-transitional society, Aboriginal Policy Research Consortium International (APRCi) Paper 295, 18 March, London, Ontario: Western University.

Kochanowicz, Jacek (2001), 'Poland and the West: In or Out?', Institut für die Wissenschaften vom Menschen (Institute for Human Sciences), accessed 18 July 2018 at http://www.iwm.at/transit/transit-online/poland-and-the-west-in-or-out/.

Lai, Daniella (2016), 'Transitional justice and its discontents: Socioeconomic justice in Bosnia and Herzegovina and the limits of international intervention', Journal of Intervention and Statebuilding, 10(3), 361-81.

Lai, Daniella and Catwerina Bonora (2019), 'The transformative potential of post-war justice initiatives in Bosnia and Herzegovina', in Matthew Evans (ed.), Transitional and Transformative Justice: Critical and International Perspectives, Abingdon: Routledge, pp. 54-76.

Lambourne, Wendy (2014), 'Transformative justice, reconciliation and peacebuilding', in Susanne Buckley-Zistel, Teresa Koloma Beck, Christian Braun and Friederike Mieth (eds), Transitional Justice Theories, Abingdon: Routledge, pp. 19-39.

Laplante, Lisa J. (2008), 'Transitional Justice and Peace Building: Diagnosing and Addressing the Socioeconomic Roots of Violence through a Human Rights Framework', International Journal of Transitional Justice, 2(3), 331-355. 
Lundy, Patricia and Mark McGovern (2008), 'Whose Justice? Rethinking Transitional Justice from the Bottom Up', Journal of Law and Society, 35(2), 265-92.

Mamdani, Mahmood (1996), 'Reconciliation Without Justice', Southern African Review of Books, 46, 3-5, accessed 20 October 2016 at http://web.archive.org/web/20020307145639/http://www.uniulm.de/*rturrell/antho3html/Mamdani.html.

Mani, Rama (2008), 'Dilemmas of Expanding Transitional Justice, or Forging the Nexus between Transitional Justice and Development', International Journal of Transitional Justice, 2(3), 253-65.

Marks, Stephen P. (2003), The Human Rights Framework for Development: Seven Approaches, Working Paper Series No. 18, François-Xavier Bagnoud Center for Health and Human Rights, Boston: Harvard School of Public Health.

Madlingozi, Tshepo (2010), 'On Transitional Justice Entrepreneurs and the Production of Victims', Journal of Human Rights Practice, 2(2), 208-28.

Matsunaga, Jennifer (2016), 'Two faces of transitional justice: Theorizing the incommensurability of transitional justice and decolonization in Canada', Decolonization: Indigeneity, Education \& Society, 5(1), 24-44.

McAuliffe, Pádraig (2017), Transformative Transitional Justice and the Malleability of Post-Conflict States, Cheltenham: Edward Elgar.

Muvingi, Ismael (2009), 'Sitting on Powder Kegs: Socioeconomic Rights in Transitional Societies', International Journal of Transitional Justice, 3(2), 163-82.

Ottendörfer, Eva, Mariam Salehi, Irene Weipert-Fenner and Jonas Wolff (2017), 'Labor Unions and Transitional Justice: An Exploratory Study on a Neglected Actor', in Roger Duthie and Paul Seils (eds), Justice Mosaics: How Context Shapes Transitional Justice in Fractured Societies, New York: International Center for Transitional Justice, pp. 344-69. 
Pasipanodya, Tafadzwa (2008), ‘A Deeper Justice: Economic and Social Justice as Transitional Justice in Nepal', International Journal of Transitional Justice, 2(3), 378-97.

Podlashuc, Leopold (2011), The South African Homeless People's Federation: Interrogating the Myth of Participation, Working Paper, African Centre for Citizenship and Democracy, Cape Town:

University of the Western Cape.

Robins, Simon (2013), Families of the Missing: A Test for Contemporary Approaches to Transitional Justice, Abingdon: Routledge.

Robins, Simon and Ram Kumar Bhandari (2012), From Victims to Actors: Mobilising Victims to Drive Transitional Justice Process, Research Report, June, Kathmandu: National Network of Families of Disappeared and Missing Nepal.

Sandoval Villalba, Clara (2011), Transitional Justice: Key Concepts, Processes and Challenges, Briefing Paper IDCR-BP-07/11, Institute for Democracy and Conflict Resolution, University of Essex, Colchester: University of Essex.

Sandoval, Clara (2017), 'Reflections on the Transformative Potential of Transitional Justice and the Nature of Social Change in Times of Transition', in Roger Duthie and Paul Seils (eds), Justice Mosaics: How Context Shapes Transitional Justice in Fractured Societies, New York: International Center for Transitional Justice, pp. 166-200.

Schmid, Evelyne and Aoife Nolan (2014), “'Do No Harm”? Exploring the Scope of Economic and Social Rights in Transitional Justice', International Journal of Transitional Justice, 8(3), 362-82.

Skaar, Elin (2011), 'Transformative aspects of formal TJ initiatives: Opportunities and limitations', paper presented at the conference 'Transformative Justice: Global Perspectives', Worldwide Universities Network International Conference, University of Leeds, Leeds, 12 May.

Sen, Amartya (1999), Development as Freedom, New York: Alfred A. Knopf. 
Selim, Yvette and Tim Murithi (2011), 'Transitional Justice and Development: Partners for Sustainable Peace in Africa?', Journal of Peacebuilding \& Development, 6(2), 58-72.

Stan, Lavinia (2009), 'Introduction: Post-communist transition, justice, and transitional justice', in Lavinia Stan (ed.), Transitional Justice in Eastern Europe and the Former Soviet Union: Reckoning with the communist past, Abingdon: Routledge, pp. 1-14.

Szczerbiak, Aleks (2017), Post-communist truth-revelation procedures as a means of political legitimation and de-legitimation: The case of Lech Wałęsa in Poland, SEI Working Paper No 143, Sussex European Institute, University of Sussex, July, Brighton: University of Sussex.

United Nations (1966), International Covenant on Economic, Social and Cultural Rights, General Assembly Resolution 2200A (XXI) of 16 December 1966, Entered into Force 3 January 1976.

Uvin, Peter (2004), Human Rights and Development, Bloomfield: Kumarian Press.

von Holdt, Karl (2013), 'South Africa: The Transition to Violent Democracy', Review of African Political Economy, 40(138), 589-604.

Waldorf, Lars (2012), 'Anticipating the Past: Transitional Justice and Socio-Economic Wrongs', Social and Legal Studies, 21(2), 171-186. 


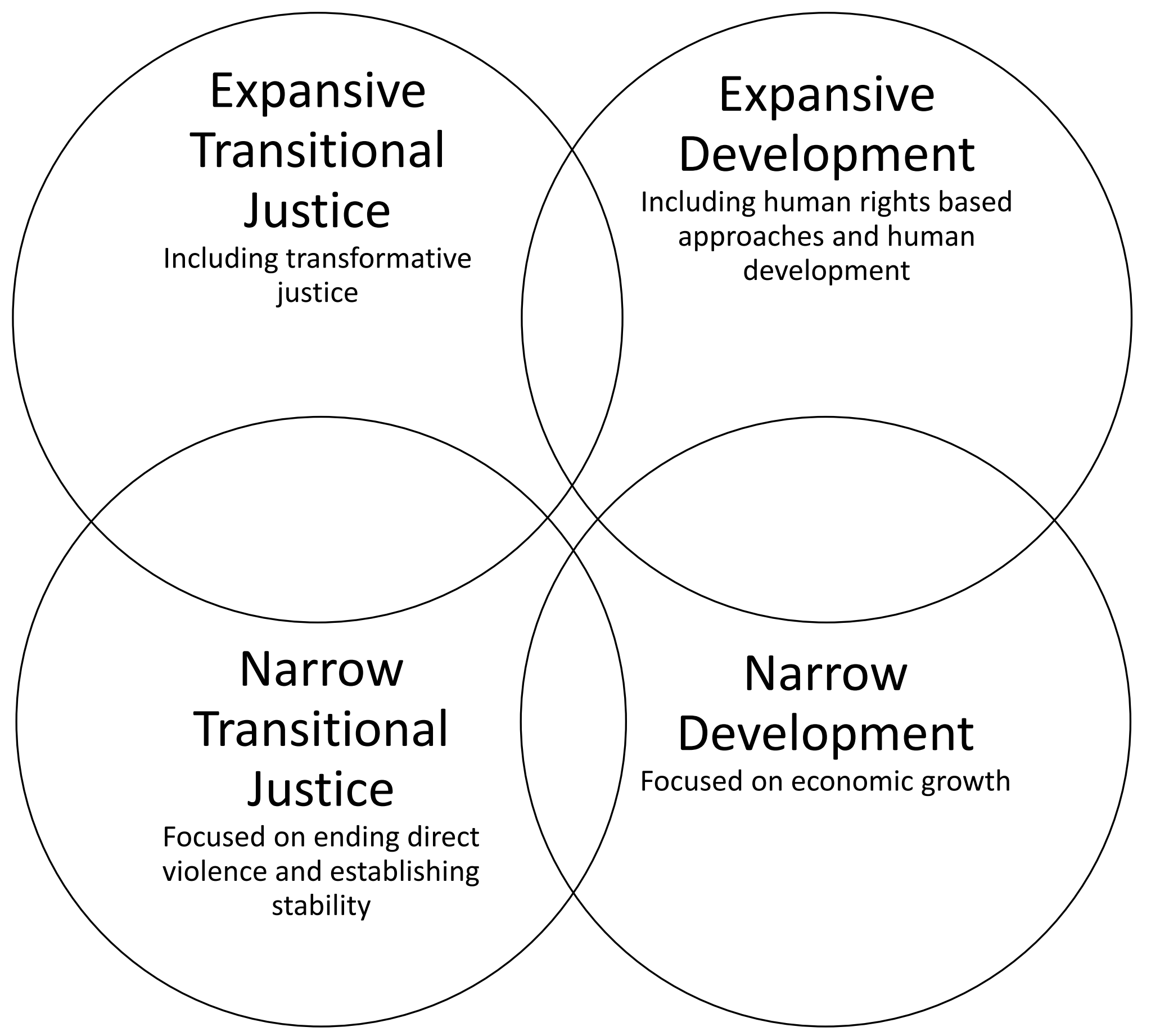

